\title{
Określanie mechanicznych właściwości skał na podstawie właściwości fizycznych przy użyciu sztucznych sieci neuronowych
}

\begin{abstract}
W niniejszej pracy opracowano szereg związków między poszukiwaną cechą geomechaniczną, w tym parametrami sprężystymi - modułem Younga $(E)$ i współczynnikiem Poissona $(v)$ oraz parametrami wytrzymałościowymi - wytrzymałością na ściskanie jednoosiowe (UCS) oraz stałą Biota $(\alpha)$, a cechami ośrodka, które najczęściej są standardowo mierzone lub szacowane dla większości obiektów złożowych. Cel pracy realizowano na obiekcie o potencjale węglowodorowym, w którym przedmiotem zainteresowania był interwał osadów dolnego paleozoiku, zdeponowanych w północnej części basenu bałtyckiego na obszarze koncesji Wejherowo. Do opracowania związków między poszukiwaną właściwością geomechaniczną ośrodka skalnego a innymi, standardowo mierzonymi lub interpretowanymi cechami fizycznymi skały zastosowano sztuczne sieci neuronowe z użyciem algorytmu wstecznej propagacji błędów (ang. back propagation). Algorytm wstecznej propagacji był wykorzystywany w środowisku oprogramowania Petrel (Schlumberger).
\end{abstract}

Słowa kluczowe: właściwości sprężyste, właściwości wytrzymałościowe, sztuczne sieci neuronowe, modelowanie geomechaniczne.

\section{Prediction of mechanical properties of rocks based on their physical properties using Artificial Neural Networks}

\begin{abstract}
In this work, a number of relationships were found between the geomechanical properties, including elastic moduli - Young's modulus $(E)$ and Poisson's ratio $(v)$ and strength properties - uniaxial compression strength (UCS) and Biot's coefficient $(\alpha)$, and commonly measured and interpreted properties, fitting in a standard exploration of the reservoir rock. For this purpose, the shale formation of lower Paleozoic age deposited in the northern part of the Baltic Basin were investigated. An artificial neural network using back propagation algorithm, was used to develop the relationship between the geomechanical properties and other, more commonly measured or interpreted physical properties of rocks.
\end{abstract}

Key words: elastic properties, strength properties, Artificial Neural Networks, geomechanical modelling.

\section{Wprowadzenie}

Parametry sprężyste i wytrzymałościowe, czyli tzw. parametry geomechaniczne, powoli stają się standardem w charakterystyce obiektów złożowych, zwłaszcza tych o charakterystyce niekonwencjonalnej, a także obiektów wytypowanych do potencjalnego składowania gazu (podziemne magazyny gazu i geologiczne składowanie $\mathrm{CO}_{2}$ ) czy odpadów radioaktywnych. Przy analizie tego typu obiektów parametry, o których mowa, odgrywają pierwszorzędną rolę, ponieważ stanowią podstawę do charakterystyki mechanicznej ośrodka, którego mechaniczne zachowanie pod wpływem ludzkiej ingerencji (eksploatacja węglowodorów, zabiegi zatłaczania medium do formacji geologicznych) powinno być zrozumiałe, a skutki tego zachowania - przewidywalne [28].

Określanie parametrów mechanicznych w warunkach laboratoryjnych wymaga, poza wykorzystaniem specjalistycznej aparatury, przygotowania cylindrycznych rdzenników z materiału skalnego, który nie wykazuje pierwotnych cech zniszczenia (spękania). Ponadto przeprowadzane testy mają najczęściej charakter niszczący. $Z$ uwagi na charakter pomiaru i częste ograniczenie dostępności odpowiedniego materiału do badań wyznaczanie parametrów geomechanicznych na materiale rdzeniowym przeprowadzane jest wybiórczo. Z kolei niska 
reprezentatywność uniemożliwia pełną charakterystykę najczęściej zmiennego w swej naturze ośrodka skalnego.

Alternatywą dla pomiarów laboratoryjnych jest szacowanie parametrów geomechanicznych formacji na podstawie zarejestrowanych cech fizycznych ośrodka skalnego w profilu otworu wiertniczego lub objętości skał objętych badaniem sejsmicznym. Zaletą tego typu pomiarów jest ciągłość zapisu, pozwalająca na pełną charakterystykę zmienności cech ośrodka wzdłuż osi otworu wiertniczego lub w objętości objętej zdjęciem sejsmicznym.

W literaturze odnoszącej się do mechaniki skały dostępnych jest wiele modeli empirycznych opisujących relację poszukiwanych parametrów mechanicznych i standardowo rejestrowanych lub interpretowanych właściwości fizycznych skał $[9,34]$. W praktyce okazuje się jednak, że w wielu przypadkach zależności te są bardzo specyficzne dla danego obiektu, pola naftowego czy basenu sedymentacyjnego i nie wszędzie można je wykorzystać.

W niniejszej pracy opracowano szereg związków między poszukiwaną cechą geomechaniczną, w tym parametrami sprężystymi - modułem Younga $(E)$ i współczynnikiem Poissona $(v)$ oraz parametrami wytrzymałościowymi - wytrzymałością na ściskanie jednoosiowe (UCS) oraz stałą Biota $(\alpha)$, a cechami ośrodka, które najczęściej są standardowo mierzone lub szacowane dla większości obiektów złożowych. Cel pracy realizowano na obiekcie o potencjale węglowodorowym, w którym przedmiotem zainteresowania był interwał osadów dolnego paleozoiku, zdeponowanych w północnej części basenu bałtyckiego.

\section{Parametry geomechaniczne}

Właściwości mechaniczne ośrodka skalnego charakteryzowane są między innymi przez parametry sprężyste i wytrzymałościowe. Sprężystość wyrażana jest za pomocą współczynnika Poissona (v) i modułów sprężystości, w tym modułu Younga $(E)$, określających relację między wielkością siły na jednostkę po- wierzchni powodującej odkształcenie na danym poziomie. Z kolei parametry wytrzymałościowe informują o maksymalnym naprężeniu prowadzącym do zniszczenia materiału [6]. Wśród parametrów wytrzymałościowych szczególnie często wykorzystywana jest wytrzymałość na ściskanie jednoosiowe (UCS) [20].

Istnieje kilka metod pomiarów parametrów geomechanicznych. Wielkości wartości statycznych parametrów geomechanicznych wyznaczane są w testach ściskania jedno- lub trójosiowego przeprowadzanych na wyciętych ze skały próbkach w kształcie walca. Dynamiczne moduły sprężystości można natomiast obliczyć na podstawie zarejestrowanych prędkości fal sprężystych: fali podłużnej $\left(v_{p}\right)$ i poprzecznej $\left(v_{s}\right)$ oraz gęstości skały $(\rho)$ według odpowiednich zależności $[8,18,27]$. Prędkości fali podłużnej $\left(v_{p}\right)$ i fali poprzecznej $\left(v_{s}\right)$ mogą być uzyskane w wyniku profilowania akustycznego lub badań sejsmicznych, a także badania ultradźwiękowego przeprowadzonego na rdzeniu lub zwiercinach $[2,14,19]$. Badania ultradźwiękowe, podobnie jak pomiary statycznych parametrów sprężystych, prowadzone są wybiórczo na wyznaczonych do badania próbkach, podczas gdy profilowanie akustyczne w otworze i badania sejsmiczne stanowią źródło ciągłej informacji na odcinku, w którym przeprowadzane jest profilowanie w otworze wiertniczym, czy też w całej objętości skał objętych badaniem sejsmicznym.

Pomimo istotnej roli, jaką pełnią parametry geomechaniczne, w tym moduły sprężystości i parametry wytrzymałościowe, ich pomiar zazwyczaj nie jest częsty, a niektóre z nich, jak np. stała Biota, w standardzie krajowym nie są mierzone wcale. Z uwagi na często napotykany problem z dostępnością odpowiedniego materiału do analiz i ich niszczący charakter coraz częściej sięga się po metody statystyczne wykorzystujące liniowe i nieliniowe zależności korelacyjne czy bardziej zaawansowane narzędzia statystyczne, określające relacje między parametrami wytrzymałościowymi a parametrami fizycznymi, zarejestrowanymi podczas profilowania w otworze czy badaniu sejsmicznym $[3,15,21]$.

\section{Metodyka}

W celu estymacji poszukiwanej cechy fizycznej ośrodka skalnego na drodze opracowywania równań empirycznych na ogół stosuje się metody statystyczne. W ostatnich latach coraz częściej angażowane są również nowe techniki z zakresu sztucznej inteligencji, które znajdują zastosowanie w opracowywaniu modeli prognostycznych pożądanej cechy. Szereg badań zajmujących się stosowaniem ANN (ang. Artificial Neural Network) w dziedzinach inżynierii wskazuje, że modele uzyskane z zastosowaniem sztucznych sieci neuronowych nie różnią się w sposób znaczący od innych metod statystycznych [11, 22].

Nadrzędnym celem użytkowników metod statystycznych w ujęciu klasycznym jest opracowanie uniwersalnej metody- ki ograniczonej konkretnymi prawami i wskazówkami. Z kolei użytkownicy ANN jako główny cel upatrują trafność predykcji i znalezienie metody, która pozwoli na uzyskanie praktycznego wyniku. W tym miejscu należy podkreślić fakt, że problemy, z którymi przychodzi mierzyć się użytkownikom z dziedziny inżynierii, są o tyle skomplikowane, że poszukiwania najczęściej dotyczą cech wielowymiarowych. Ze względu na funkcjonalność stosowania i wszechstronność, a także zazwyczaj złożony charakter związków między badanymi parametrami a parametrami, którymi dysponujemy, stosowanie technik zaprzęgających sztuczną inteligencję coraz częściej wykazuje zdecydowaną przewagę [12]. 
W niniejszej pracy przedstawiono konstrukcję przestrzennych modeli parametrycznych przy wykorzystaniu zarówno prostych funkcji regresji liniowych lub nieliniowych, jak też technik sztucznej inteligencji, w tym sieci neuronowych i algorytmu genetycznego (strukturalnie opartego na ANN), do predykcji modułów sprężystości - modułu Younga $(E)$, i współczynnika Poissona $(v)$ oraz parametrów wytrzymałościowych (UCS) i stałej Biota $(\alpha)$ korelowanych z innymi cechami fizycznymi skały, np. rejestrowanymi w badaniu geofizycznym - prędkościami sprężystej fali podłużnej ( $v p)$, czy cechami standardowo interpretowanymi, takimi jak: gęstość, porowatość, zawartość minerałów ilastych czy zawartość węgla organicznego TOC.

Do konstrukcji modeli, w których zastosowano metody statystyczne i techniki sztucznej inteligencji, wykorzystano dane o szerokim spektrum, tj. wyniki pomiarów laboratoryjnych oraz wyniki badań geofizycznych prowadzonych zarówno w odwiertach, jak i w całej objętości badanych skał.

\section{Sztuczne sieci neuronowe z algorytmem wstecznej propagacji błędów}

W niniejszej pracy do określenia związków między poszukiwaną właściwością geomechaniczną ośrodka skalnego a innymi, standardowo mierzonymi lub interpretowanymi cechami fizycznymi skały zastosowano sztuczne sieci neuronowe z użyciem algorytmu wstecznej propagacji błędów (ang. back propagation). Koncepcja sztucznych sieci neuronowych była przedmiotem wielu publikacji, a szczegóły dotyczące historii ich powstania, podziału na poszczególne typy oraz mechanizmu działania zostały opisane przez Bishopa [5], Samarasinghe [25] czy Haykina [17].

Sztuczne sieci neuronowe stanowią zespół elementów obliczeniowych tworzących warstwę wejściową, ukrytą i warstwę wyjściową (rysunek 1). Nadrzędnym celem przy stosowaniu jednokierunkowych sieci neuronowych z algorytmem wstecznej propagacji błędu jest znalezienie szeregu wag łączących $w_{i j}$ (ang. connection weights) takich, aby możliwe było dokładne odtworzenie par danych wejściowych/wyjściowych (input/output) dla danego zestawu danych. W momencie znalezienia optymalnych wag wyuczona sieć jest poddana testowaniu przy użyciu niezależnego zestawu danych, tzw. ciągu weryfikującego, dla którego uprzednio wyuczony przez sieć związek między danymi wejściowymi i wyjściowymi zostaje wykorzystany w postaci wyrażenia matematycznego.
Tego typu podejście nosi nazwę uczenia się sieci z nadzorem (ang. supervised learning). Podstawą stosowania wyuczonych sieci neuronowych jest zatem podstawowy związek między danymi wejściowymi i wyjściowymi, uchwycony przez wielokrotnie optymalizowane i finalne połączenie wag uzyskane w fazie uczenia sieci. W tej fazie każdy neuron oblicza sumę wag wejściowych przejmowanych z warstwy poprzedzającej, zgodnie z poniższym wzorem:

$$
x_{i}^{\text {out }}=f\left(\Sigma_{j} w_{i j} x_{j}^{i n}\right)+\theta_{i}
$$

gdzie, $x_{i}^{\text {out }}$ to wynik, $f(x)$ to nieliniowa funkcja transferu (ang. transfer function), np. w postaci funkcji sigmoidalnej, $x_{j}^{\text {in }}$ to dane wejściowe, a $\theta_{i}$ to błąd systematyczny (ang. bias) [30, 33].

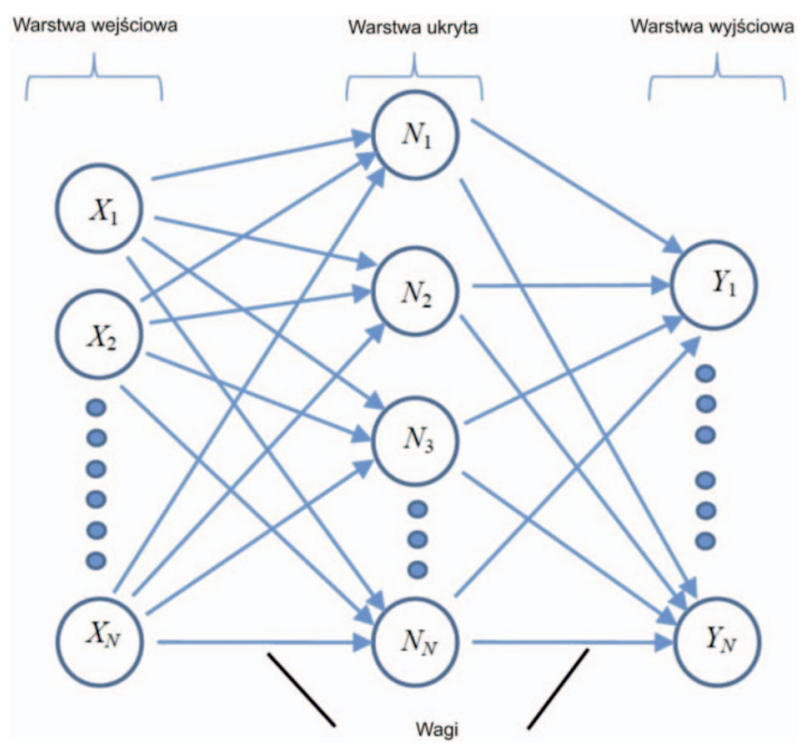

Rys. 1. Schemat działania jednokierunkowej sieci neuronowej (ang. feed forward $A N N$ ) przedstawiający sztuczne neurony połączone w postaci warstwy wejściowej, ukrytej i wyjściowej

Uczenie sztucznej sieci neuronowej odbywa się poprzez minimalizację funkcji błędu, mającej postać:

$$
\mathrm{ERR}=\Sigma_{p} \Sigma_{i}\left[t_{i}^{(p)} O_{i}^{(p)}\right]^{2}
$$

gdzie $p$ oznacza numer wypracowanego wzorca, $t_{i}^{(p)}$ to docelowa wartość wyjściowa, $O_{i}^{(p)}$ to wartość wyjściowa sieci neuronowych. Minimalizacja funkcji błędu odbywa się iteracyjnie przy wykorzystaniu równań różniczkowych cząstkowych stosowanych w odniesieniu do wag i błędu systematycznego. W niniejszej pracy algorytm wstecznej propagacji był wykorzystywany w środowisku oprogramowania Petrel (Schlumberger).

\section{Określanie związków między poszukiwanymi parametrami geomechanicznymi a innymi parametrami fizycznymi skały}

W niniejszej pracy na potrzeby znalezienia związków między poszukiwanymi parametrami geomechanicznymi wy- korzystano wyniki badań geofizycznych przeprowadzonych w otworze i w wolumenie skał objętych badaniem oraz wyniki 
Tablica 1. Zestawienie wejściowych danych statycznych parametrów geomechanicznych

\begin{tabular}{|l|c|c|c|c|}
\hline Parametr & $\begin{array}{c}\text { L-1 } \\
\text { (liczba prób) }\end{array}$ & $\begin{array}{c}\text { O-2 } \\
\text { (liczba prób) }\end{array}$ & $\begin{array}{c}\text { O-3 } \\
\text { (liczba prób) }\end{array}$ & (liczba prób) \\
\hline Wytrzymałość UCS & 63 & - & - & - \\
\hline Moduł Younga & 124 & 60 & 60 & 10 \\
\hline Współczynnik Poissona & 122 & 60 & 9 & 7 \\
\hline Stała Biota & $\begin{array}{c}\text { interpretacja w postaci krzywej } \\
\text { geofizyki otworowej }\end{array}$ & - & $\begin{array}{c}\text { interpretacja w postaci krzywej } \\
\text { geofizyki otworowej }\end{array}$ \\
\hline
\end{tabular}

pomiarów statycznych wartości poszukiwanych parametrów (tablica 1). Dla wytrzymałości na ściskanie jednoosiowe (UCS) wykorzystano 63 wyniki pomiarów wytrzymałości wykonanych na rdzeniu wiertniczym $\mathrm{z}$ otworu L-1 w interwale formacji łupkowej (w ramach realizacji zadania $10 \mathrm{w}$ projekcie MWSSSG Polskie Technologie dla Gazu Łupkowego nr BG1/ MWSSSG/13), natomiast dla modułów sprężystości wykorzystano bogatą bazę w postaci około 200 wyników pomiarów statycznych modułu Younga i współczynnika Poissona opracowaną na podstawie badań z odwiertów L-1, O-2, O-3 i O-4 dostarczonych przez PGNiG SA - partnera przemysłowego w projekcie MWSSSG Polskie Technologie dla Gazu Łupkowego nr BG1/MWSSSG/13). W przypadku stałej Biota użyto wyników interpretacji tego parametru na podstawie skalibrowanego wynikami badań laboratoryjnych modelu petrofizycznego i litologicznego. Szczegóły dotyczące metody określenia stałej Biota można znaleźć w publikacji Stadtmüllera et al. [31].

Wyniki pomiarów i interpretacji statycznych parametrów geomechanicznych zestawiono z innymi cechami fizycznymi skały, które potencjalnie powinny wykazywać związek z poszukiwanymi parametrami geomechanicznymi i jednocześnie znajdują się w standardzie wykonywanych badań czy interpretacji. I tak w przypadku wytrzymałości na ściskanie jednoosiowe UCS wartości statyczne tego parametru zestawiono z porowatością całkowitą (Porosity_total), gęstością właściwą (Bulk_density), dynamicznymi parametrami sprężystymi, takimi jak moduł Younga (YM_dyn) i współczynnik Poissona (PR_dyn), i prędkością fali podłużnej ( $v_{p \_}$calc) [10]. Spośród parametrów sprężystych statyczny moduł Younga porównano z gęstością (Density_2) i porowatością całkowitą (Porosity_total) oraz z dynamicznym modułem Younga $(E)$, obliczonym na podstawie zarejestrowanych w otworach prędkości fali podłużnej i poprzecznej oraz wyników profilowania gęstości, natomiast statyczny współczynnik Poissona zestawiono z zawartością minerałów ilastych ( $\mathrm{VClc}$ ), zawartością węgla organicznego (TOC), z gęstością (Density_2) i prędkością fali podłużnej $\left(v_{p}\right)$. W przypadku stałej Biota wyniki interpretacji porównano z gęstością objętościową (Rhob_despiked), porowatością efektywną (Phie_nd) i dynamicznym modułem Younga (E_POZ).
Jak już wspomniano, dobranie zestawu parametrów treningowych nie było przypadkowe. Otóż duża wytrzymałość skał osadowych jest między innymi konsekwencją kompakcji i innych zachodzących procesów diagenetycznych, w wyniku których dochodzi do zwiększenia stopnia konsolidacji osadów, ich zagęszczenia i zabudowywania przestrzeni międzyziarnowej precypitującymi roztworami i minerałami podlegającymi przemianom w podwyższonych temperaturach i ciśnieniach [6]. Opisane powyżej zmiany przekładają się na zwiększenie sztywności materiału, w którym propagacja fal sprężystych zachodzi szybciej [26, 35]. W przypadku modułu Younga porównywano go z parametrami petrofizycznymi (gęstość objętościowa i porowatość efektywna) pośrednio wskazującymi sztywność materiału [32].

Dobór zestawu treningowego w przypadku analizy współczynnika Poissona był oparty na wcześniej opisywanych w literaturze zależnościach, np. między pozytywną korelacją wyrażającego plastyczność współczynnika Poissona a zawartością minerałów ilastych lub negatywną korelacją między zawartością substancji organicznej (TOC) a poszukiwanym współczynnikiem Poissona [13].

Natomiast w przypadku stałej Biota ogólnie stwierdzono zależność między jej wielkością a stopniem konsolidacji osadów $[1,24]$. Skutkiem tego będzie zależność wielkości stałej Biota od porowatości, malejącej wraz ze wzrostem stopnia konsolidacji osadów, które na skutek pogrzebania na wyższych głębokościach podlegają kompakcji i różnym procesom diagenetycznym prowadzącym do wzrostu gęstości osadu. Moduł Younga z kolei, wskazując sztywność materiału, osiąganą w osadach o wyższym stopniu konsolidacji [4], intuicyjnie powinien wykazywać pozytywną korelację z poszukiwanym współczynnikiem Biota.

W poszukiwaniu związków między badanymi parametrami na obszarze analizowanego i modelowanego obiektu posłużono się sztucznymi sieciami neuronowymi (ang. Artificial Neural Networks). Proces uczenia sieci neuronowych odbywał się z nadzorem (ang. supervised) przy wykorzystaniu zestawu treningowego, jak opisano wyżej. Wyuczona sieć neuronowa została następnie poddana weryfikacji. Ciągiem weryfikującym były zbiory wyników pomiarów statycznych poszukiwanych parametrów - wytrzymałości na ściskanie jednoosiowe, 

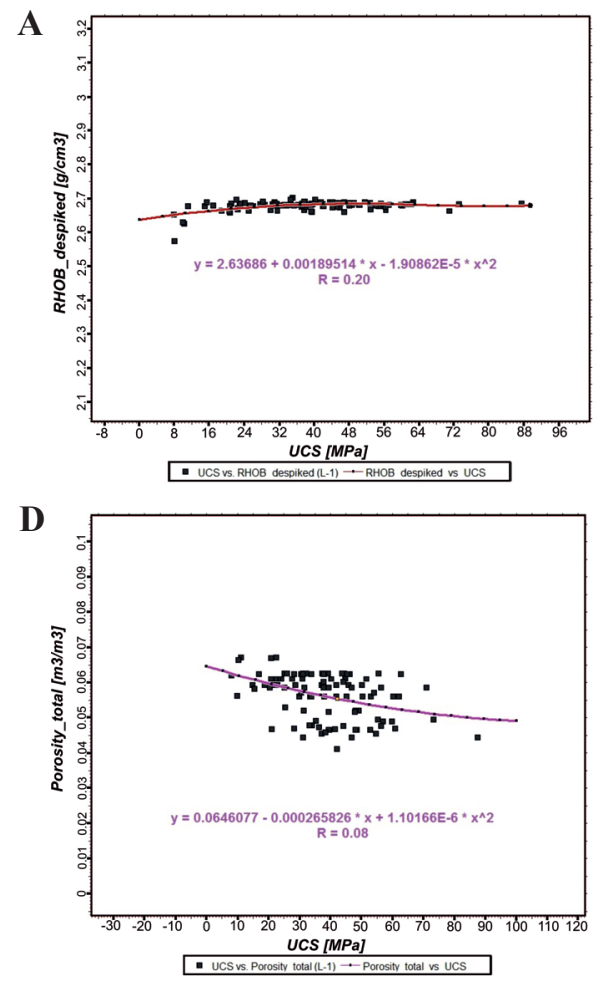
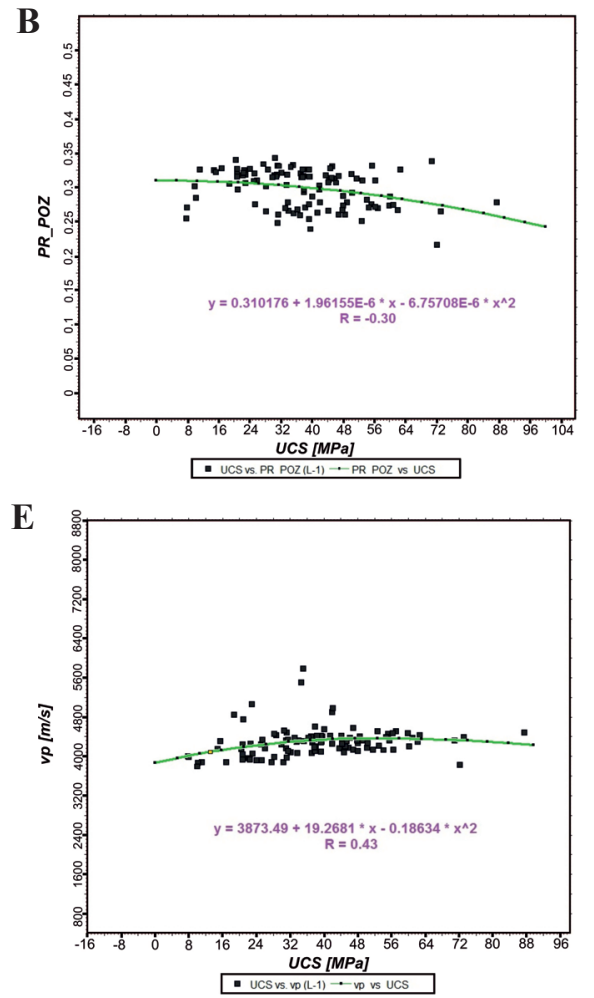

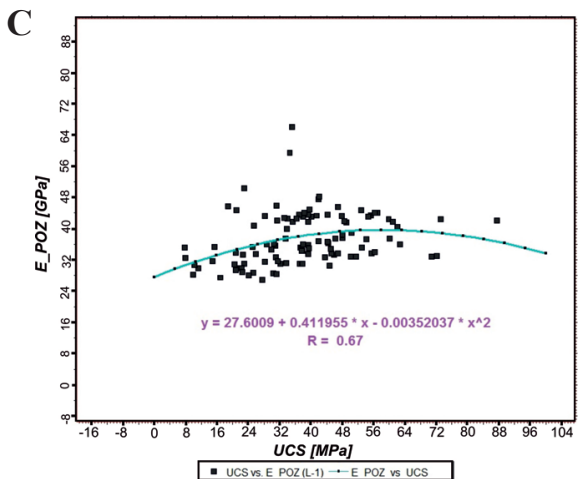

Rys. 2. Zależność gęstości $\rho$ (RHOB_ despiked) (A), współczynnika Poissona $v$ (PR POZ) (B), modułu Younga (E_POZ) (C), porowatości całkowitej $\phi$ (Porosity total) (D) i prędkości fali podłużnej $(V p)(\mathrm{E})$ w postaci ciągłego zapisu z odwiertu L-1 od statycznej wytrzymałości na ściskanie jednoosiowe zmierzonej w prasie ściskającej (UCS)

Tablica 2. Zestawienie współczynników korelacji poszczególnych parametrów wykorzystanych w procesie uczenia sztucznych sieci neuronowych na podstawie danych geofizyki wiertniczej w celu oszacowania wytrzymałości na ściskanie jednoosiowe (UCS) (rodzaje korelacji: nieliniowe)

\begin{tabular}{|c|c|c|c|c|c|c|}
\hline Correlation type: & Linear & & & & & $\checkmark ?$ \\
\hline & Porosity_total & Bulk_density & vp_calc & PR_dyn & YM_dyn & UCS_bar_UW \\
\hline Porosity_total & 1.0000 & 0.4866 & 0.8465 & 0.7763 & 0.8691 & 0.2952 \\
\hline Bulk_density & 0.4866 & 1.0000 & 0.4618 & 0.2651 & 0.4334 & 0.1483 \\
\hline vp_calc & 0.8465 & 0.4618 & 1.0000 & 0.7601 & 0.9803 & 0.3934 \\
\hline PR_dyn & 0.7763 & 0.2651 & 0.7601 & 1.0000 & 0.8701 & 0.6041 \\
\hline YM_dyn & 0.8691 & 0.4334 & 0.9803 & 0.8701 & 1.0000 & 0.4886 \\
\hline Total & 0.8822 & 0.5576 & 0.9982 & 0.9891 & 0.9990 & 0.7289 \\
\hline
\end{tabular}

modułu Younga, współczynnika Poissona oraz wyników interpretacji stałej Biota.

Zależność między poszczególnymi parametrami z zestawu treningowego a statycznymi parametrami geomechanicznymi została określona przez zastosowanie współczynników korelacji $R$, zaprezentowanych na diagramach krzyżowych zesta- wianych parametrów: wytrzymałości na ściskanie jednoosiowe UCS (rysunek 2), modułu Younga $E$ (rysunek 3), współczynnika Poissona $v$ (rysunek 4) i stałej Biota $\alpha$ (rysunek 5).

Łączne, ważone współczynniki korelacji dla poszczególnych parametrów były na ogół wysokie i kolejno wynosiły: 0,7289 dla wytrzymałości na ściskanie, 0,7967 dla modułu
A

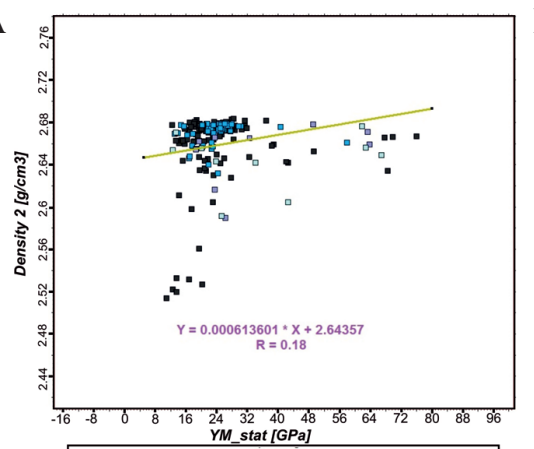

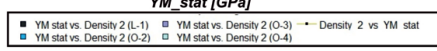

B

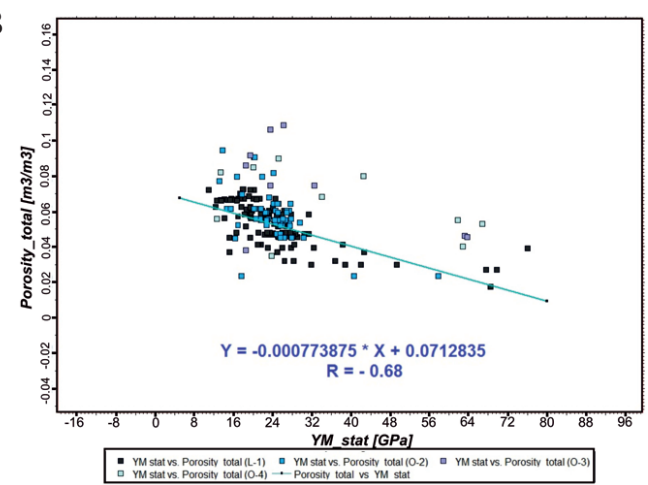

$\mathrm{C}$

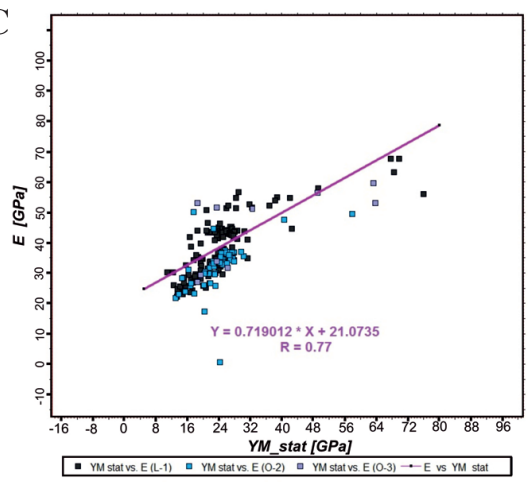

Rys. 3. Zależność gęstości $\rho$ (Density) (z lewej), porowatości całkowitej $\phi$ (Porosity_total) (w środku) i dynamicznego modułu

Younga E (z prawej) w postaci ciągłego zapisu z odwiertów L-1, O-2, O-3 i O-4 od statycznego modułu Younga (YM_stat) 


\section{NAFTA-GAZ}

Younga, 0,5066 dla współczynnika Poissona i 0,7502 dla stałej Biota. Opracowane zależności zostały następnie wykorzy- stane do przygotowania rozkładów tych parametrów w przestrzeni 3D modelowanych formacji łupkowych.

Tablica 3. Zestawienie współczynników korelacji poszczególnych parametrów wykorzystanych $\mathrm{w}$ procesie uczenia sztucznych sieci neuronowych na podstawie danych geofizyki wiertniczej w celu oszacowania statycznego modułu Younga (YM_stat) (rodzaje korelacji: liniowe)

Correlation type: Linear
\begin{tabular}{|l|r|r|r|r|}
\hline & RHOB_despiked & PHI_tot_despiked & E & YM stat \\
\hline Density 2 & 1.0000 & 0.4290 & 0.4924 & 0.2194 \\
\hline Porosity_total & 0.4290 & 1.0000 & 0.8382 & 0.6686 \\
\hline E & 0.4924 & 0.8382 & 1.0000 & 0.7736 \\
\hline Total & 0.4933 & 0.8384 & 0.8510 & 0.7967 \\
\hline
\end{tabular}

A

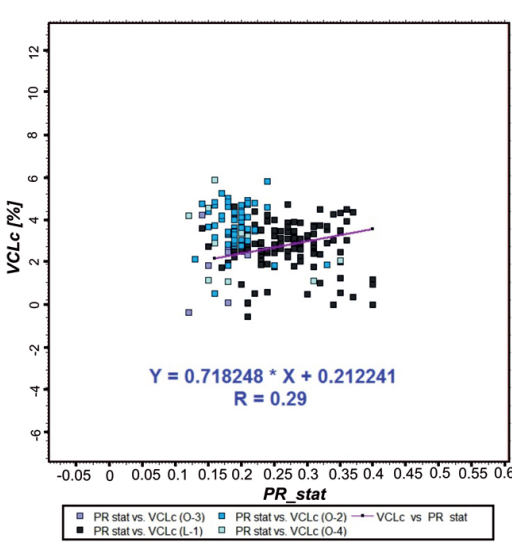

C

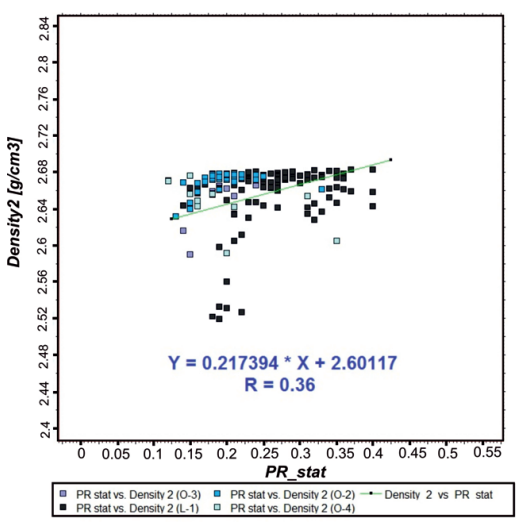

B

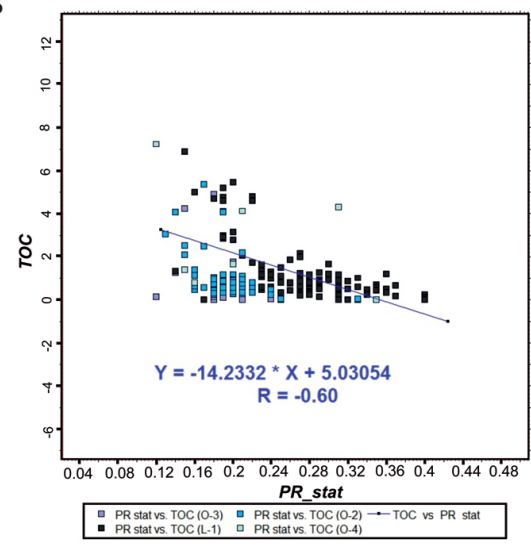

D

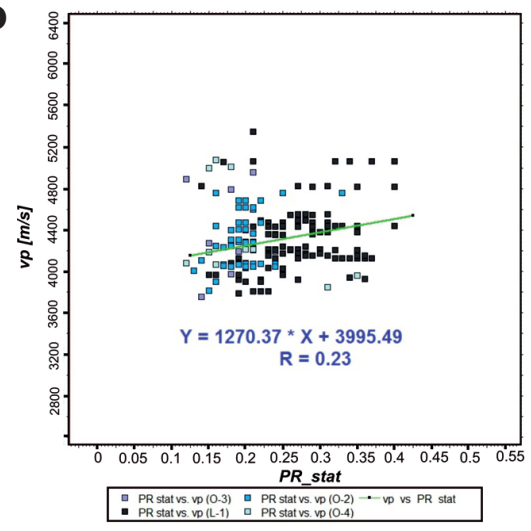

Rys. 4. Zależność zawartości minerałów ilastych ( $\mathrm{VclC})(\mathrm{A})$, zawartości węgla organicznego (TOC) (B), gęstości $\rho$ (Density) (C) i prędkości fali podłużnej ( $V p)(\mathrm{D})$ w postaci ciągłego zapisu z odwiertów: L-1, O-2, O-3 i O-4 od statycznego współczynnika Poissona (PR_stat)

Tablica 4. Zestawienie E korelacji poszczególnych parametrów wykorzystanych w procesie uczenia sztucznych sieci neuronowych na podstawie danych geofizyki wiertniczej w celu oszacowania statycznego współczynnika Poissona (PR_stat) (rodzaje korelacji: liniowe)

\begin{tabular}{|c|c|c|c|c|c|}
\hline Correlation type: & Linear & & & & ? ? \\
\hline & VCLC & TOC & RHOB_despike & vp & PR stat \\
\hline VCLC & 1.0000 & 0.0420 & 0.0712 & 0.5153 & 0.2245 \\
\hline TOC & 0.0420 & 1.0000 & 0.7814 & 0.4243 & 0.4012 \\
\hline Density 2 & 0.0712 & 0.7814 & 1.0000 & 0.3793 & 0.4102 \\
\hline vp & 0.5153 & 0.4243 & 0.3793 & 1.0000 & 0.2129 \\
\hline Total & 0.5910 & 0.7938 & 0.7992 & 0.6739 & 0.5066 \\
\hline
\end{tabular}


A

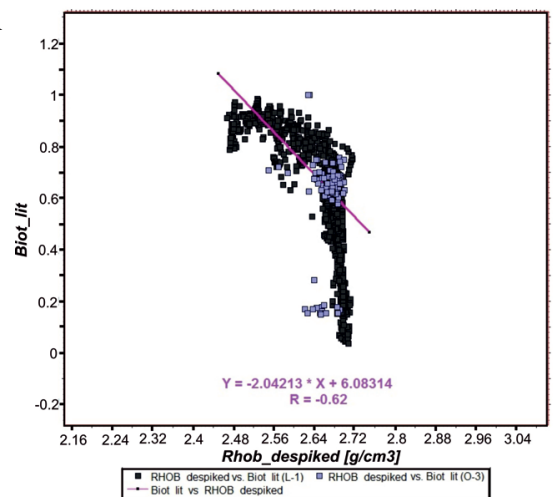

B

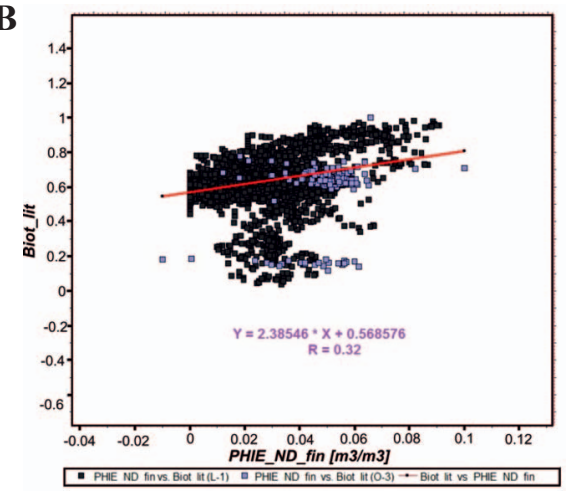

C

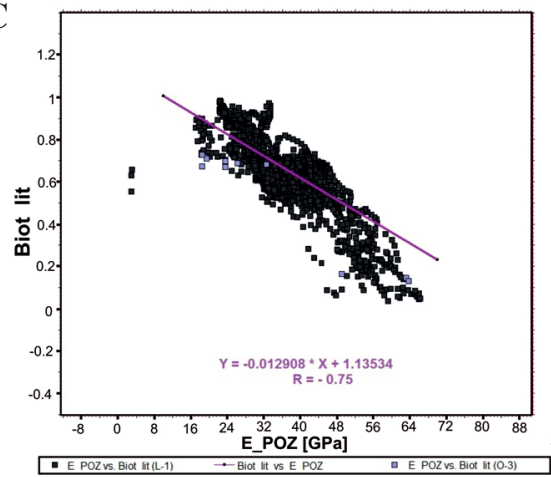

Rys. 5. Zależność gęstości $\rho$ (RHOB_despiked) (z lewej), porowatości całkowitej $\phi$ (PHI_ND_fin) (w środku) i dynamicznego modułu Younga (E_POZ) (z prawej) w postaci ciągłego zapisu z odwiertu L-1 (szare kwadraty) i O-3 (fioletowe kwadraty widoczne 2 podzbiory wynikają z interpretacji stałej Biota przeprowadzonej w wybranych interwałach) od stałej Biota $\alpha$ (Biot_lit)

Tablica 5. Zestawienie współczynników korelacji poszczególnych parametrów wykorzystanych w procesie uczenia sztucznych sieci neuronowych na podstawie danych geofizyki wiertniczej w celu oszacowania stałej Biota $\alpha$ (Biot_lit) (rodzaje korelacji: liniowe)

\begin{tabular}{|l}
\begin{tabular}{|l|r|r|r|r|}
\hline & & & \\
\hline & RHOB_despiked & PHIE_ND_fin & \multicolumn{1}{c|}{ E_POZ } & Biot_lit \\
\hline RHOB_despike & 1.0000 & 0.5919 & 0.2856 & 0.2317 \\
\hline PHIE_ND_fin & 0.5919 & 1.0000 & 0.3068 & 0.1662 \\
\hline E_POZ & 0.2856 & 0.3068 & 1.0000 & 0.7443 \\
\hline Total & 0.6020 & 0.6091 & 0.3328 & 0.7502 \\
\hline
\end{tabular}
\end{tabular}

\section{Szacowanie przestrzennych rozkładów parametrów geomechanicznych w przestrzeni 3D}

Etap interpolacji modelowanych parametrów geomechanicznych z wykorzystaniem wyuczonych przez sieci neuronowe wzorców został poprzedzony analizą statystyczną danych wejściowych. Pozwoliło to na określenie parametrów sterujących sposobem interpolacji danych wejściowych w przestrzennej siatce modelu blokowego.

Zakresy zmienności modelowanych parametrów określono na podstawie statystycznej analizy danych otworowych o kroku próbkowania dostosowanym do rozdzielczości modelu blokowego, podczas której dokonano wyboru teoretycznego modelu wariogramu i wartości zasięgu strefy oddziaływania w kierunku pionowym i poziomym. Ostatni parametr określa liniową zależność średniego zróżnicowania określonego parametru, w tym przypadku wytrzymałości, od średniej odległości między punktami pomiarowymi.

Wariogramy wykreślone dla kierunku pionowego dla poszczególnych odwiertów, z których pochodziły dane wejściowe modelowanych parametrów, pozwoliły na określenie wartości zasięgu strefy oddziaływania w kierunku pionowym, które dla kolejnych parametrów w całym profilu wynosiły: $31,11 \mathrm{~m}$ w otworze L-1 dla wytrzymałości UCS (rysunek 6), 30,492 m w otworze L-1, 30,032 $\mathrm{m}$ w otworze O-2, 29,777 m w otworze O-3 i 29,963 m w otworze O-4 dla modułu Younga (rysunek 7) oraz 19,231 m w otworze L-1 i 27,879 m w otworze O-3 dla stałej Biota $\alpha$ (rysunek 9).

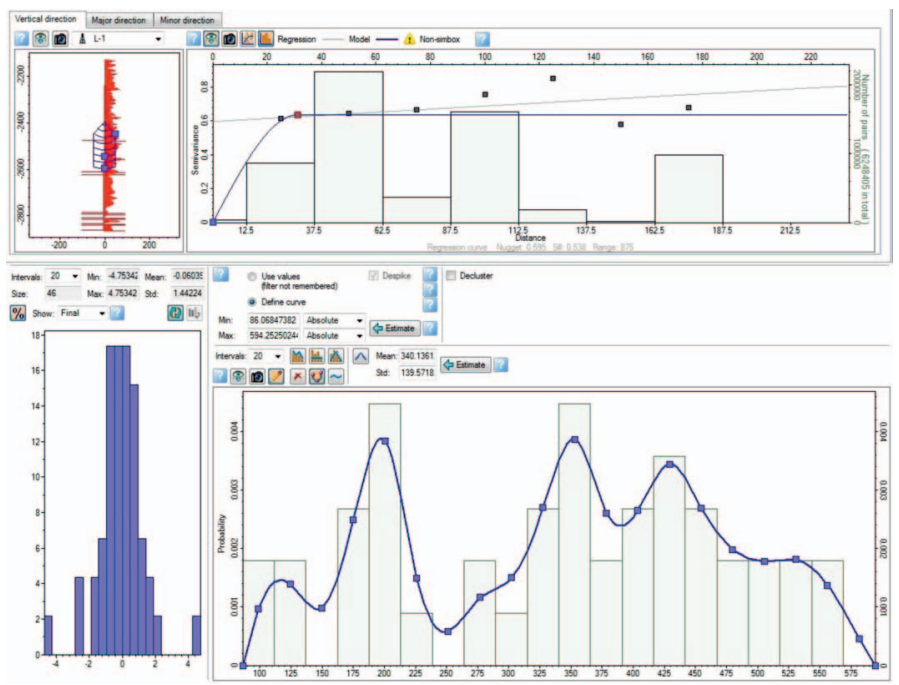

Rys. 6. Wykres funkcji semiwariogramu wytrzymałości na ściskanie jednoosiowe (UCS_bar) w kierunku pionowym w pełnym profilu występowania danych w otworze L-1 (model teoretyczny oznaczony fioletową linią oraz semiwariogram eksperymentalny oznaczony punktami) (u góry), histogram przedstawiający rozkład wartości modelowanej wytrzymałości na ściskanie jednoosiowe (UCS_bar) (na dole)

W przypadku analizy statystycznej współczynnika Poissona niewystarczająca ilość danych, a zwłaszcza zbyt mała liczba prób w otworze O-3 (9 prób) i O-4 (7 prób) sprawiły, że wykreślone wariogramy dla kierunku pionowego $\mathrm{w}$ tych otworach 

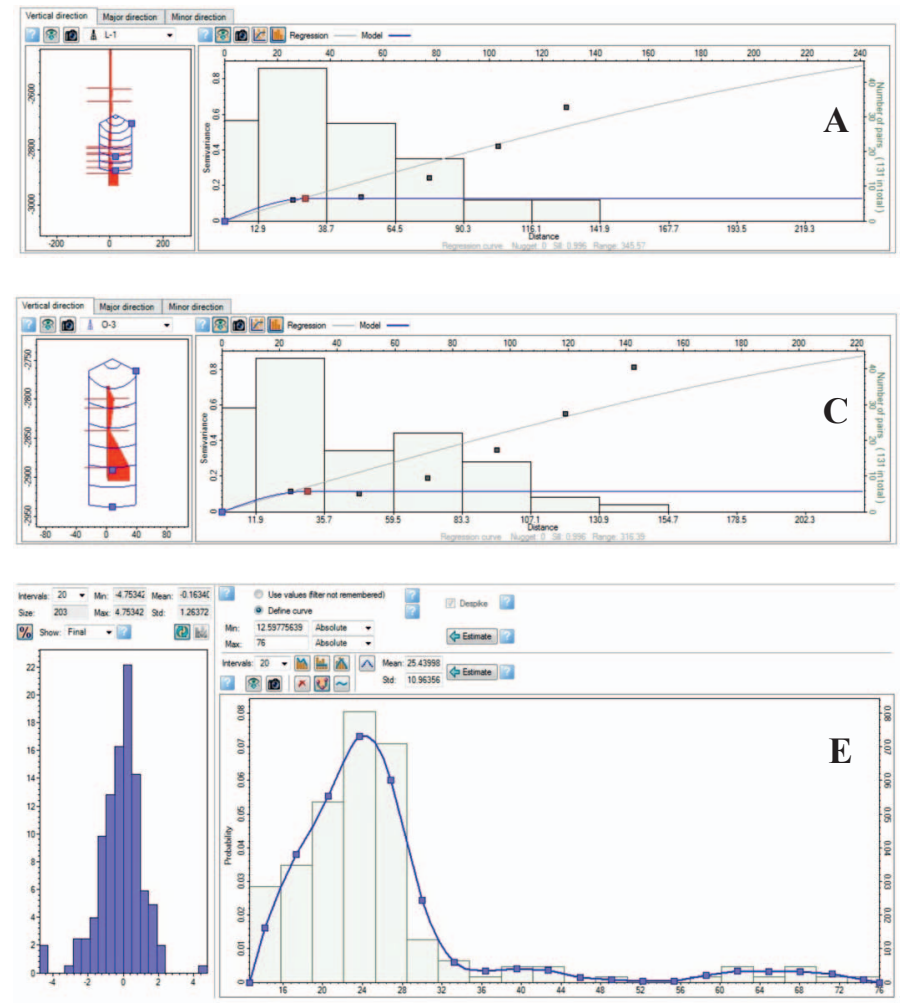

były pozbawione struktury i w związku z tym ich analiza była niemożliwa. Na określenie wartości zasięgu strefy oddziaływania pozwoliły wariogramy wykreślone dla otworu L-1 oraz O-2, na podstawie których ustalono, że parametr ten wynosi kolejno 47,191 oraz 45,829 (rysunek 8).

Zaprezentowane kolejne histogramy (rysunki 6-9) przedstawiają rozkłady wartości modelowanych parametrów. Na zamieszczonych histogramach obserwuje się, że w pełnym profilu dominują łupki o wytrzymałości na ściskanie jednoosio-
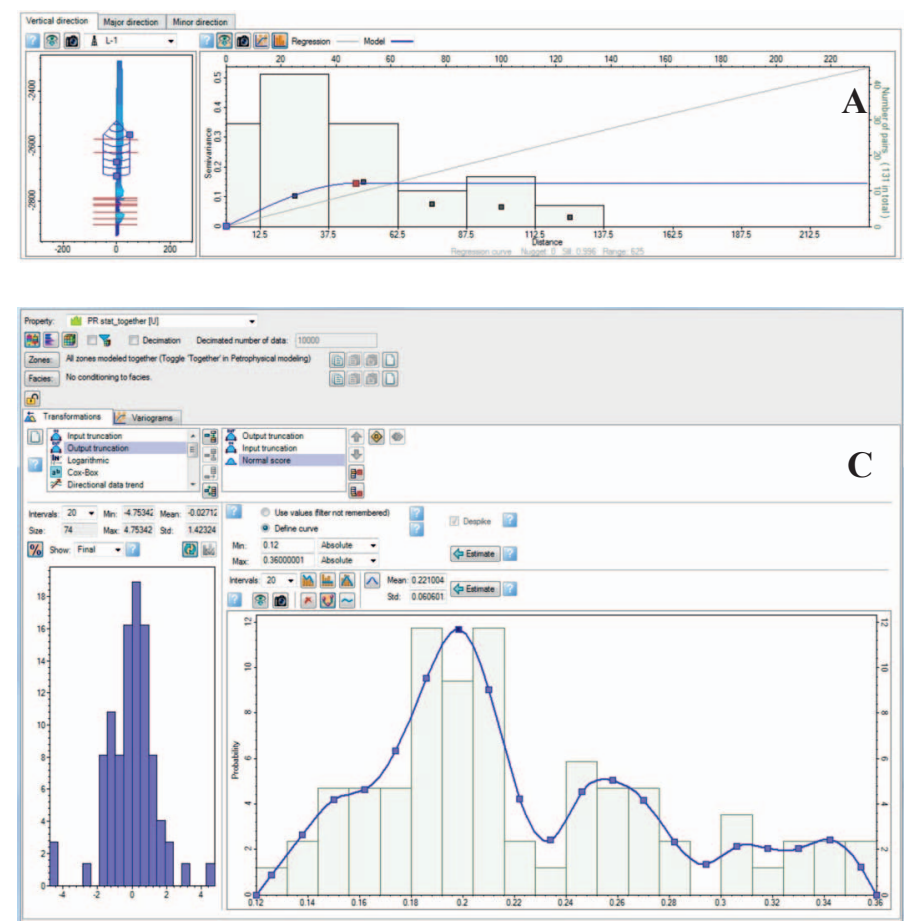
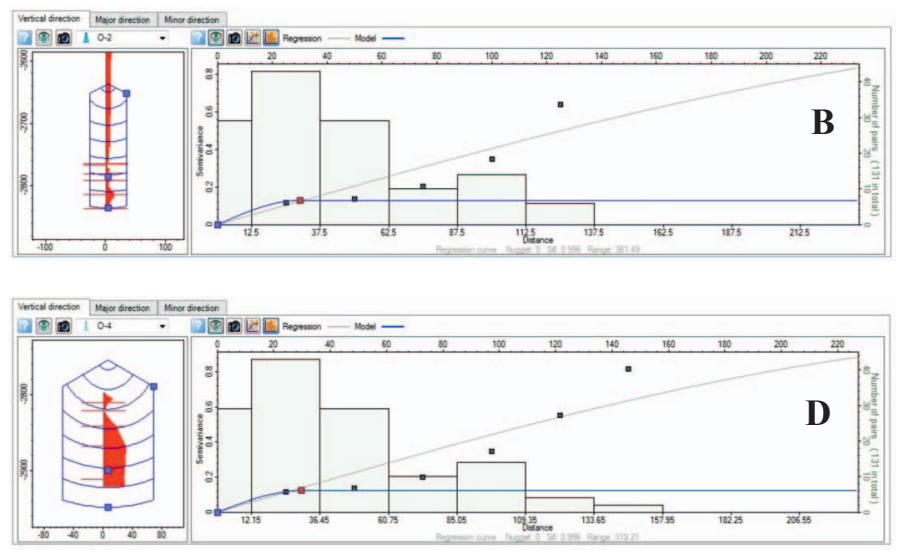

Rys. 7. Wykres funkcji semiwariogramu statycznego modułu Younga (YM_combined) w kierunku pionowym w pełnym profilu występowania danych w otworze L-1 (A), O-2 (B), O-3 (C) i O-4 (D) (model teoretyczny oznaczony fioletową linią oraz semiwariogram eksperymentalny oznaczony punktami), histogram przedstawiający rozkład wartości modelowanego modułu Younga w pełnym profilu formacji łupkowej (E)

we rzędu 400 $\div 480$ bar (rysunek 6). Dla porównania skały łupkowe formacji Marcellus przyjmują wytrzymałości na ściskanie jednoosiowe na poziomie 550 bar [23].

Modelowane skały lupkowe reprezentowane są przez skały o sztywności wyrażonej modułem Younga na poziomie $20 \div 28 \mathrm{GPa}$ (środek rozkładu) (rysunek 7E) oraz plastycznością na poziomie $0,18 \div 0,20$ (rysunek $8 \mathrm{C}$ ). Nie odbiega to bardzo od własności amerykańskich łupków z formacji Marcellus ze współczynnikiem Poissona na poziomie 0,19 [16].

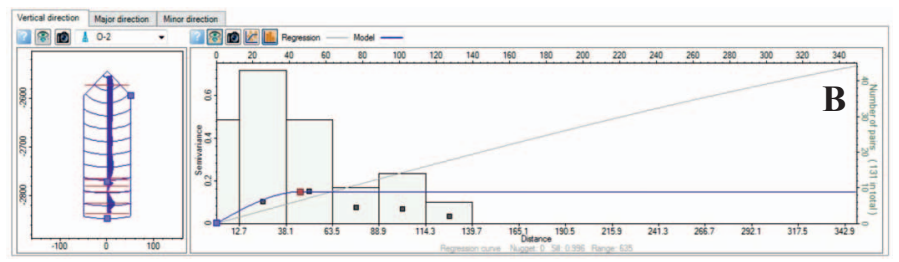

Rys. 8. Wykres funkcji semiwariogramu statycznego współczynnika Poissona (PR_combined) w kierunku pionowym w pełnym profilu występowania danych w otworach L-1 (A) i O-2 (B) (model teoretyczny oznaczony fioletową linią oraz semiwariogram eksperymentalny oznaczony punktami), histogram przedstawiający rozkład wartości modelowanego współczynnika Poissona w pełnym profilu formacji łupkowej (C) 

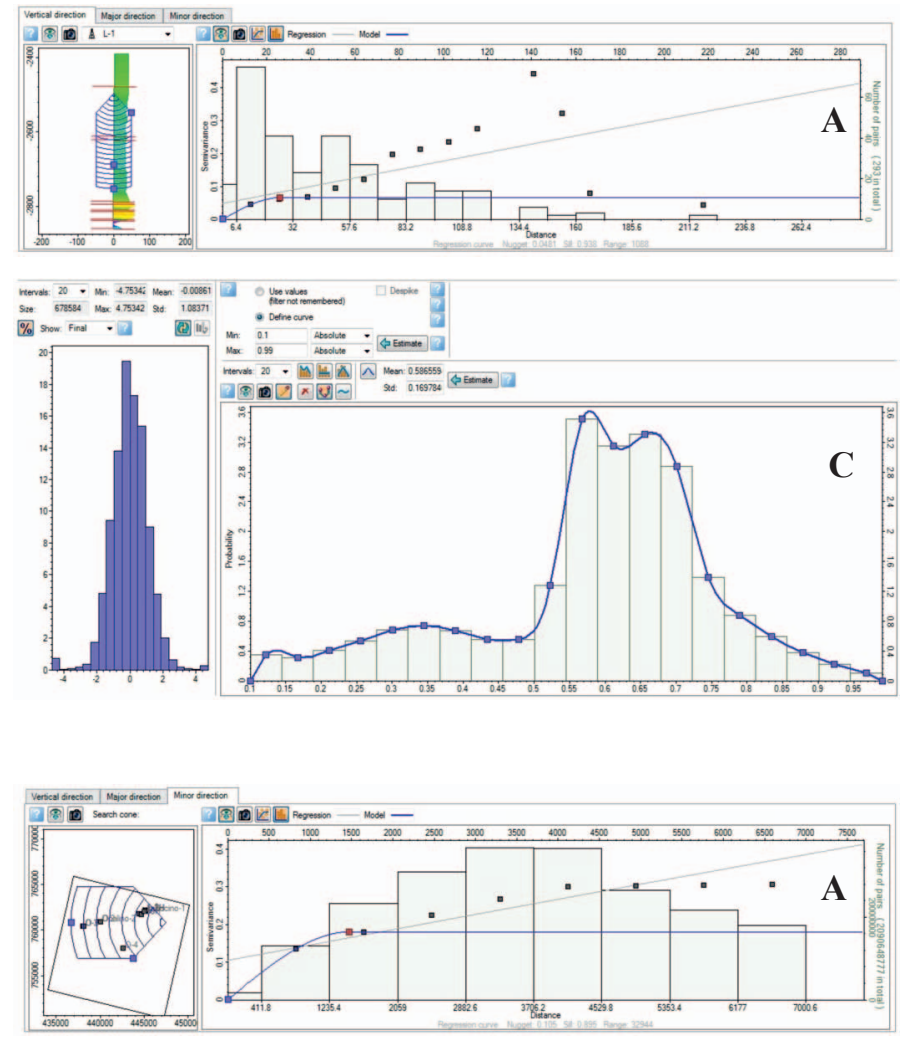

Rys. 10. Diagram przedstawiający semiwariogram dla kierunku poziomego wyznaczający minimalny (z lewej) i maksymalny (z prawej) zakres oddziaływania

Zróżnicowanie wartości współczynnika Biota w modelu blokowym zostało określone za pomocą modelu histogramu wykreślonego dla pełnego profilu i przedstawionego na rysunku 9C. Na zamieszczonym histogramie obserwuje się, że w modelowanej formacji łupkowej najwyższy udział mają utwory ze współczynnikiem Biota w zakresie wartości $0,55 \div 0,72$. Dla porównania stała Biota w formacji gazonośnych łupków Marcellus (USA) przyjmuje wartości na poziomie 0,6 [23].

$\mathrm{Z}$ uwagi na ograniczony zestaw danych parametry informujące o zmienności modelowanej wytrzymałości w kierunku poziomym, a więc minimalny i maksymalny zakres oddziaływania w tym kierunku, zostały ustalone na podstawie analizy semiwariogramu wykreślonego dla prędkości propagacji fali podłużnej $\left(v_{p}\right)$ - parametru dostępnego we wszystkich otworach, który ponadto wykazuje dodatnią korelację nie tylko z wytrzymałością na ściskanie osiowe, lecz także z innymi modelowanymi parametrami geomechanicznymi.

$\mathrm{Na}$ podstawie analizy semiwariogramu poziomego określono zbliżony pod względem wartości minimalny (ang. minor direction) i maksymalny zakres oddziaływania (ang. major direction) na poziomie odpowiednio: 1474,208 m i 1862,246 m (kolejno na rysunkach 10A i B).

Na podstawie ,wyuczonych" przez sieci neuronowe zależności między porównywanymi parametrami obliczono rozkłady poszukiwanych parametrów geomechanicznych w profilu paleozoicznych formacji łupkowych modelu blokowego.
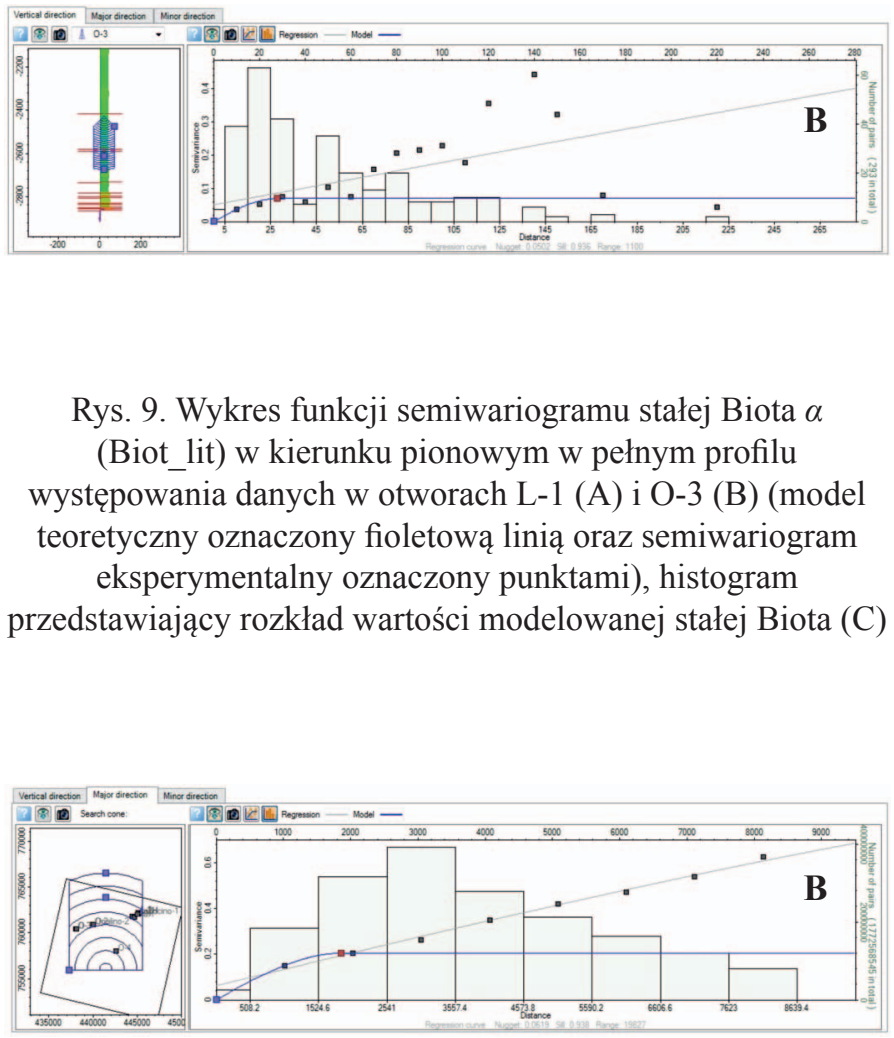

Rys. 9. Wykres funkcji semiwariogramu stałej Biota $\alpha$

(Biot_lit) w kierunku pionowym w pełnym profilu występowania danych w otworach L-1 (A) i O-3 (B) (model teoretyczny oznaczony fioletową linią oraz semiwariogram eksperymentalny oznaczony punktami), histogram przedstawiający rozkład wartości modelowanej stałej Biota (C)

Zmienności obliczonych parametrów w przestrzeni 3D, tj. wytrzymałości na ściskanie jednoosiowe UCS, modułu Younga E, współczynnika Poissona $v$ i stałej Biota $\alpha$, zostały przedstawione na rysunkach 11-14.

Na podstawie opracowanego rozkładu przestrzennego wytrzymałości na ściskanie jednoosiowe poddanych analizie dolnopaleozoicznych skał łupkowych widać, że charakteryzują się one wytrzymałością na ściskanie jednoosiowe w zakresie od około $8 \mathrm{MPa}$ (strefy oznaczone kolorem fioletowym) do $72 \mathrm{MPa}$ (kolor czerwony), ze średnią na poziomie około $33 \mathrm{MPa}$ (kolor niebieski). W strefie wzbogaconej w materię organiczną występują dwie grupy skał łupkowych: o niższej wytrzymałości, na poziomie około $10 \mathrm{MPa}$ (strefy oznaczone kolorem fioletowym), oraz liczniej reprezentowane skały o wyższej wytrzymałości, z wartościami UCS na poziomie $28 \div 45 \mathrm{MPa}$ (strefy oznaczone kolorami od jasnoniebieskiego do zielonego). Sprężystość analizowanych skał łupkowych wyrażona za pomocą modułu Younga i współczynnika Poissona zawiera się odpowiednio w przedziale od $12 \mathrm{GPa}$ (kolor fioletowy) do około $70 \mathrm{GPa}$ (kolory od pomarańczowego do czerwonego), ze średnią równą $18 \mathrm{GPa}$ (kolor ciemnoniebieski) dla modułu Younga, oraz w przedziale od 0,13 (kolor różowy) do 0,31 (kolor czerwony), ze średnią wartością współczynnika Poissona równą 0,18 (kolor niebieski). $\mathrm{W}$ interwale o podniesionym potencjale węglowodorowym skały łupkowe znajdują się w dolnym zakresie sztywności, 


\section{NAFTA-GAZ}
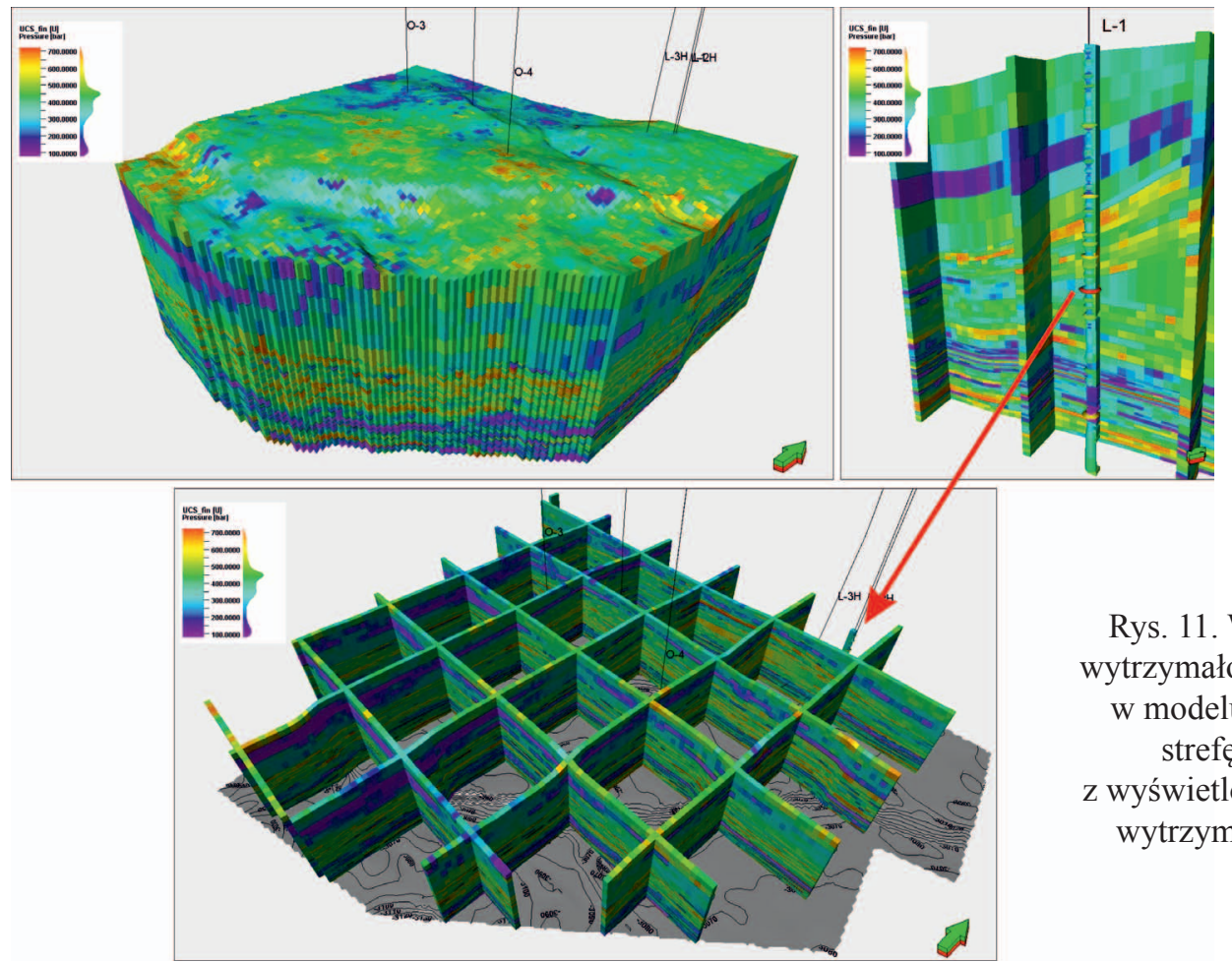

Rys. 11. Wizualizacja przestrzennej zmienności wytrzymałości na ściskanie jednoosiowe obliczonej w modelu blokowym (z lewej), przybliżenie na strefę przyotworową odwiertu L-1 wraz

z wyświetlonym zestawieniem wyników pomiarów wytrzymałości w prasie ściskającej (well logs) (z prawej)
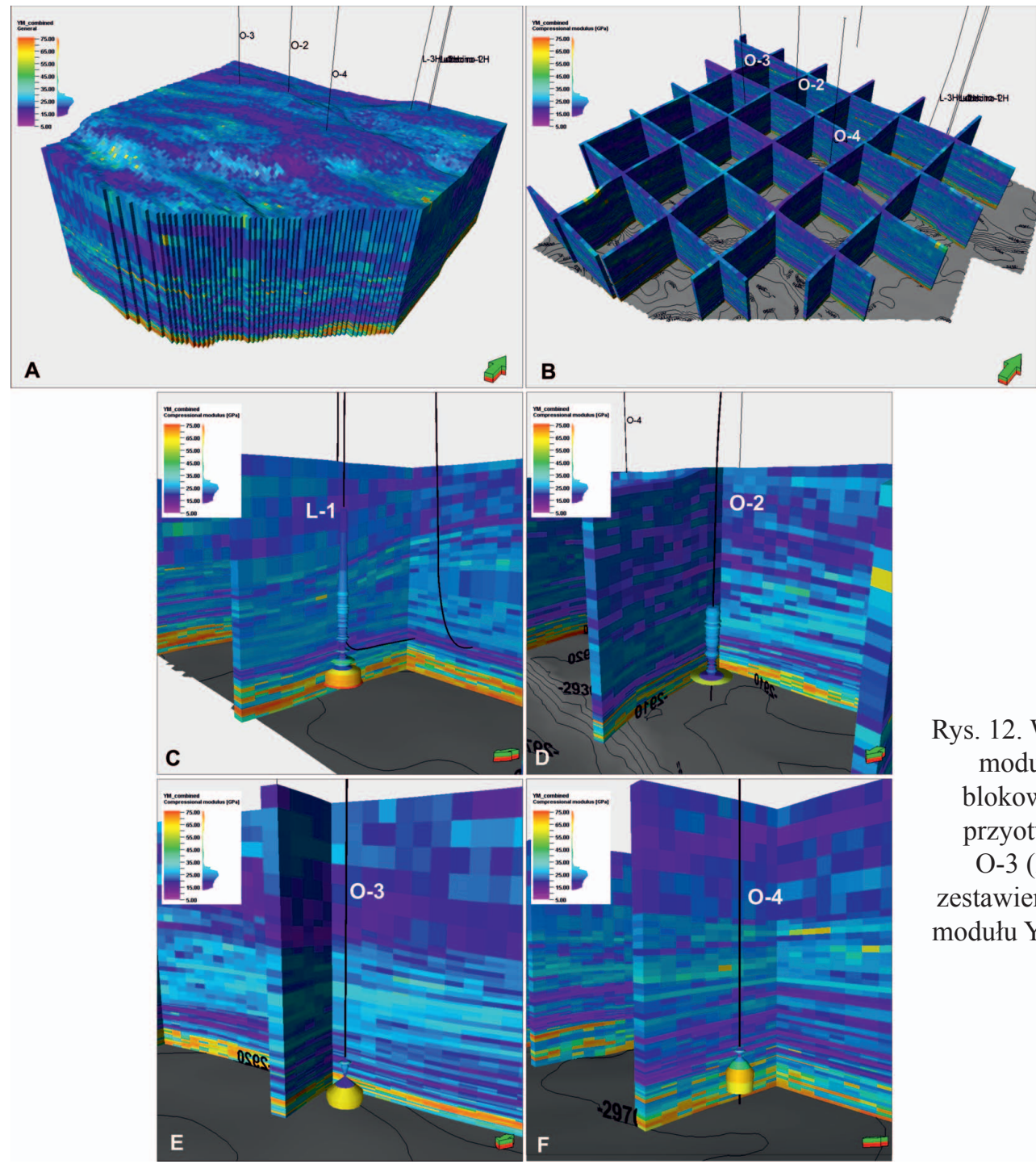

Rys. 12. Wizualizacja przestrzennej zmienności modułu Younga obliczonego w modelu blokowym (u góry), przybliżenie na strefę przyotworową odwiertu L-1 (C), O-2 (D), O-3 (E) i O-4 (F) wraz z wyświetlonym zestawieniem wyników pomiarów statycznego modułu Younga w prasie ściskającej (well logs) 
z modułem Younga na poziomie od 12 GPa do 20 GPa i współczynnikiem Poissona w zakresie 0,15 (kolor fioletowy) do 0,2 (kolor niebieski). Stała Biota dla tych skał mieści się w przedziale od 0,15 do 1, ze średnią równą 0,69 (kolor ja- snozielony), przy czym w strefie o podwyższonym potencjale węglowodorowym skały łupkowe cechuje stała Biota na poziomie wyższym, od 0,76 do 0,88 (kolory od żółtego do pomarańczowego).

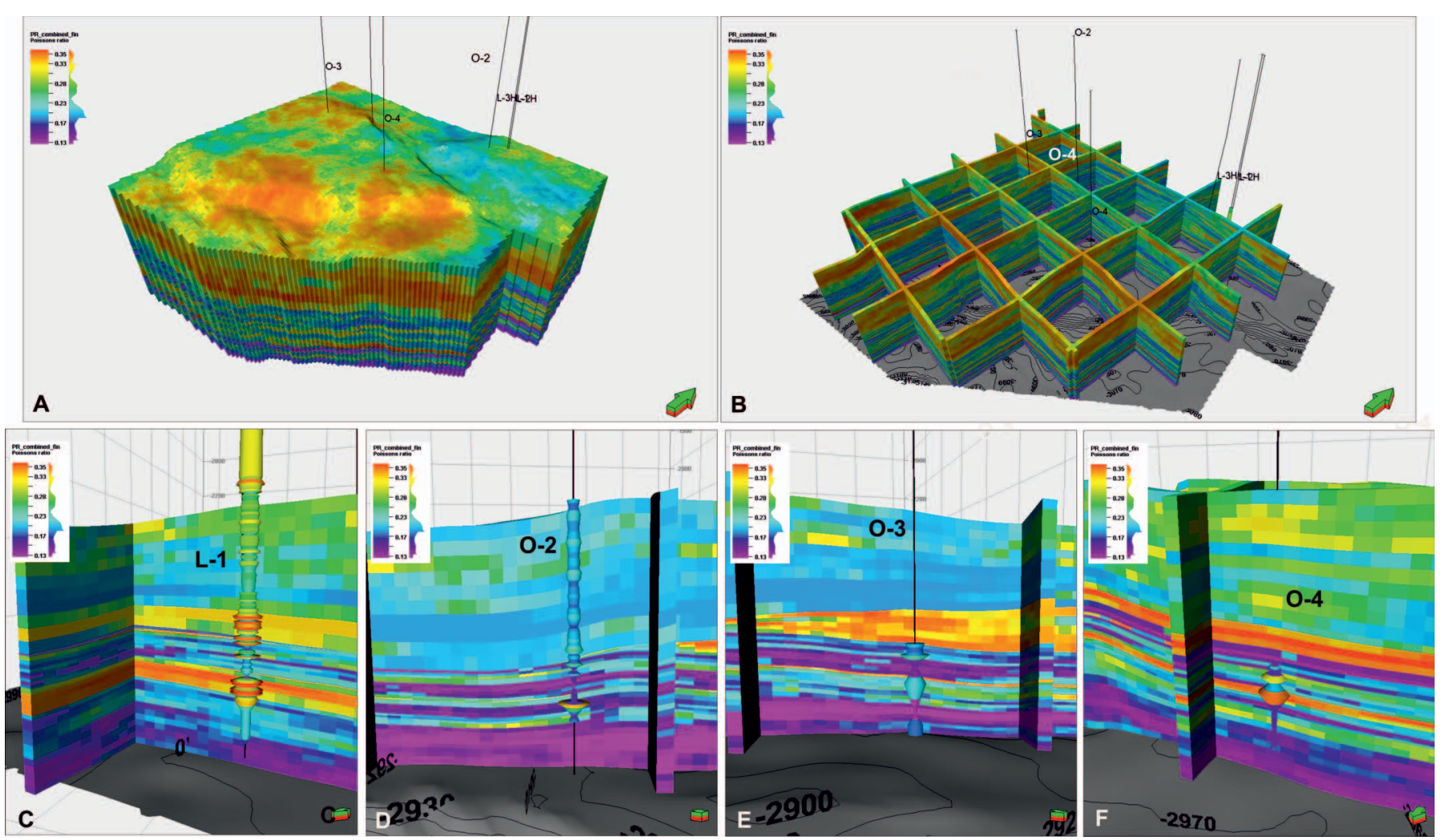

Rys. 13. Wizualizacja przestrzennej zmienności współczynnika Poissona obliczonego w modelu blokowym (u góry), przybliżenie na strefę przyotworową odwiertu L-1 (C), O-2 (D), O-3 (E) i O-4 (F) wraz z wyświetlonym zestawieniem wyników pomiarów współczynnika Poissona w prasie ściskającej (well logs)

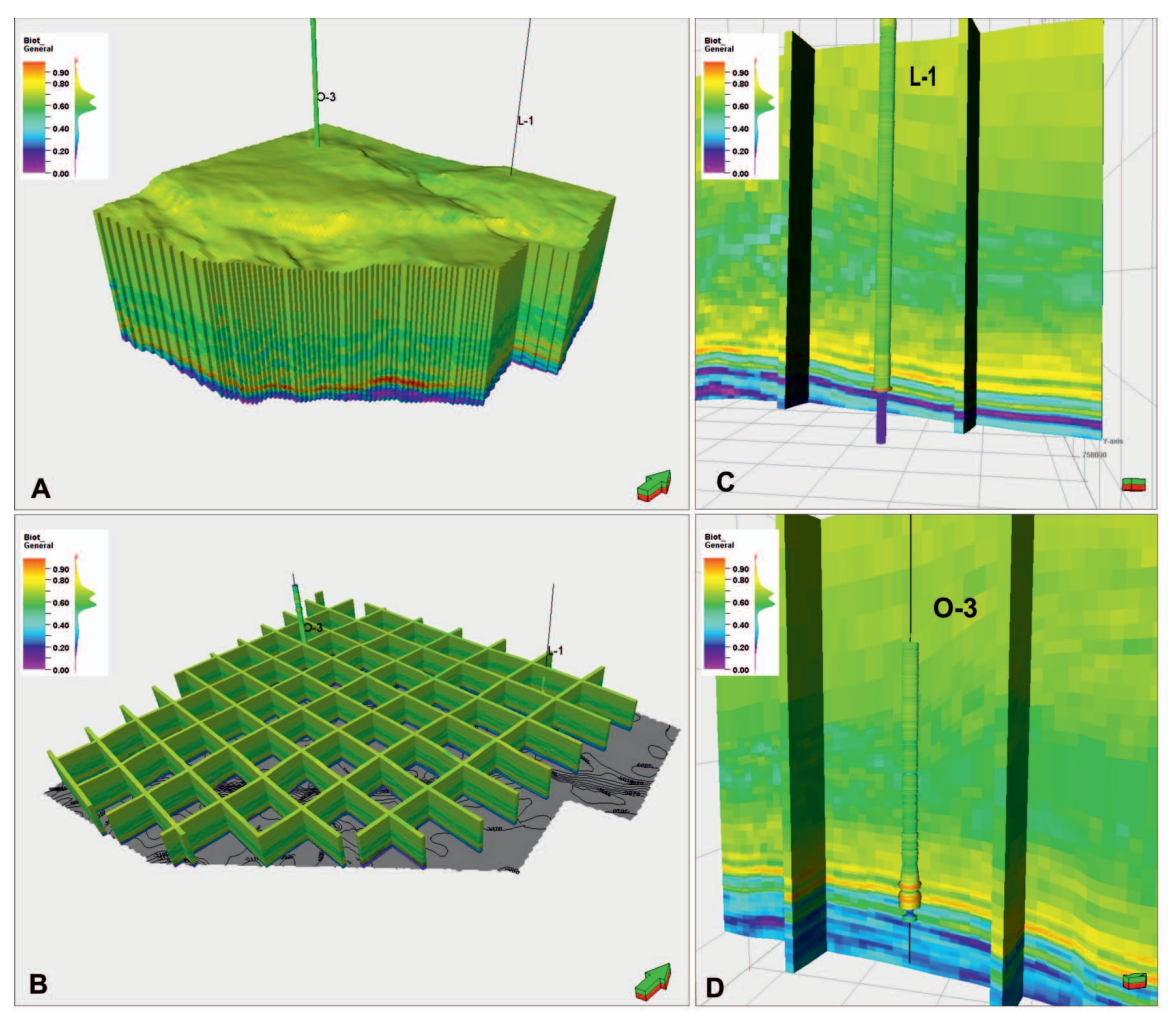

Rys. 14. Wizualizacja przestrzennej zmienności stałej Biota $\alpha$ obliczonej w modelu blokowym (z lewej - A i B), przybliżenie na strefę przyotworową

odwiertu wraz z wyświetlonym zestawieniem wyznaczonej stałej Biota (well $\log s$ ) w odwiertach L-1 (C) i O-3 (D) 


\section{Podsumowanie}

W niniejszej pracy przedstawiono wykorzystanie wyników badań geofizycznych, zarówno tych prowadzonych w profilu odwiertu, jak i w całym wolumenie skał, oraz wyników pomiarów laboratoryjnych do określenia cieszących się coraz większym zainteresowaniem parametrów geomechanicznych. Laboratoryjne badania parametrów geomechanicznych często nie są przewidziane w zestawie standardowo wykonywanych badań mających na celu rozpoznanie formacji skalnych o potencjale węglowodorowym. Dzieje się tak z wielu przyczyn, np. w wyniku częstej niedostępności reprezentatywnego do badań materiału rdzeniowego czy zwyczajnego ograniczenia budżetu na planowane badania. Znajomość parametrów geomechanicznych staje się coraz bardziej doceniana, zwłaszcza w przypadku rozpoznania formacji o charakterze niekonwencjonalnym, które najczęściej do uzyskania produkcji na poziomie uzasadnionym ekonomicznie wymagają zabiegów stymulacji (np. na drodze szczelinowania hydraulicznego). Optymalizacja tych ostatnich zasadniczo nie jest możliwa bez rozpoznania właściwości mechanicznych stymulowanego ośrodka skalnego. Ponadto parametry geomechaniczne wykorzystywane są również na bardzo wczesnych etapach rozpoznania danego obiektu o potencjale złożowym, tj. przy projektowaniu samego procesu wiercenia czy uzbrojenia odwiertów.
Praca opisuje procedurę wykorzystania i przedstawienia zależności uzyskanych na drodze zestawienia poszukiwanych cech mechanicznych z cechami skały, które albo bezpośrednio rejestruje badanie geofizyczne, albo stanowią standardowy element interpretacji obiektu o potencjale węglowodorowym. Analizowanymi relacjami między zestawianymi cechami fizycznymi ośrodka były niekiedy proste funkcje regresji liniowej, a czasem złożone związki nieliniowe, określane z wykorzystaniem metod sztucznej inteligencji (sieci neuronowe i algorytm genetyczny).

Powszechnie określane cechy fizyczne skały, w tym: porowatość, gęstość, prędkość propagacji fali sprężystej, zawartość minerałów ilastych czy zawartość węgla organicznego TOC, razem z uzyskanymi zależnościami wykorzystano do predykcji ciągłej informacji na temat zmienności poszukiwanej cechy najpierw w profilu odwiertów, a następnie w modelu blokowym lub w całym wolumenie analizowanego ośrodka geologicznego.

Otrzymane wyniki rozkładów statycznych wartości parametrów sprężystych i wytrzymałościowych w przestrzeni 3D mogą potencjalnie zostać wykorzystane do dalszej analizy geomechanicznej, np. do określenia pola naprężeń i odkształceń w badanym ośrodku skalnym, a uzyskane rozkłady dynamiczne mogą stanowić informację jakościową przy optymalizacji wiercenia i projektowaniu zabiegów stymulacji niekonwencjonalnych formacji złożowych.

Autorka sktada podziękowania Grupie PGNiG SA za zezwolenie na wykorzystanie danych.

Prosimy cytować jako: Nafta-Gaz 2018, nr 5, s. 343-355, DOI: 10.18668/NG.2018.05.01

Artykuł nadesłano do Redakcji 5.12.2017 r. Zatwierdzono do druku 30.03.2018 r.

Prezentowane wyniki były finansowane częściowo w ramach zadania w projekcie MWSSSG Polskie Technologie dla Gazu Łupkowego $\mathrm{nr}$ BG1/MWSSSG/13, a częściowo w ramach pracy statutowej pt. Opracowanie empirycznych zależności parametrów fizycznych i mechanicznych skat - praca INiG - PIB na zlecenie MNiSW; nr zlecenia: 42/SG/17, nr archiwalny: DK-4100-0042/2017.

\section{Literatura}

[1] Alam M.M., Borre M.K., Fabricius I.L., Hedegaards K., Rogen B., Hossain Z., Krogsboll A.S.: Bio's coefficient as an indicator of strength and porosity reduction: Calcareous sediments from Kerguelen Plateau. Journal of Petroleum Science and Engineering 2010, vol. 70, nr 3-4, s. 282-297.

[2] Bała M.: Parametry sprężyste łupków zawierajacych materię organiczna określone na podstawie teoretycznych relacji Biota-Gassmana i Kustera-Toksöza. Nafta-Gaz 2015, nr 12 , s. 1005-1016, DOI: 10.18668/NG2015.12.09.

[3] Barton N.: Rock Quality, Seismic Velocity, Attenuation and Anisotropy. Taylor \& Francis Group, London, UK 2007, 756 s.

[4] Biot M.A., Willis D.G.: The Elastic Coefficients of the Theory of Consolidation. Journal of Applied Mechanics 1957, vol. 24, s. 594-601.

[5] Bishop C.M.: Neural networks for pattern recognition. Oxford University Press 1995, 482 s.
[6] Bjørlykke K., Høeg K., Haque Mondol M.: Introduction to Geomechanics: Stress and Strain in Sedimentary Basins. [W:] K. Bjørlykke (ed.): Petroleum Geoscience: From sedimentary Environments to Rock Physics. Springer Science \& Business Media, Berlin 2010, s. 281-298.

[7] Bjørlykke K., Jahren J., Mandol N.H., Marcussen O., Croize D., Peltonen C., Thyberg B.: Sediment Compaction and Rock Properties. Search and Discovery Article 50192, 2009. Adapted from poster presentation at AAPG International Conference and Exhibition, Cape Town, South Africa 26-29.10.2008.

[8] Bratton T., Cooper I.: Wellbore Measurements: Tools, Techniques, and Interpretation. [W:] Aadnoy B., Cooper I., Miska S., Mitchell R., Payne M. (eds.): Advanced Drilling and Well Technology. Society of Petroleum Engineers 2009, s. 443-457.

[9] Butel N., Hossack A., Kizil M.: Prediction of in situ rock strength using sonic velocity. Extended abstracts from $14^{\text {th }}$ 
Coal Operators' Conference, University of Wollongong, The Australasian Institute of Mining and Metallurgy \& Mine Managers Association, Australia 12-14.02.2014, s. 89-102.

[10] Chang Ch., Zoback M.D., Khaksar A.: Empirical relations between rock strength and physical properties in sedimentary rocks. Journal of Petroleum Science and Engineering 2006, vol. 51, nr 3-4, s. 223-237.

[11] Cordon H.R.A., van Hoogstraten R.: Key Issues for Successful Industrial Neural Network Applications: an Application in Geology. [W:] Braspenning P.J., Thuijsman F., Weijters A.J.M.M. (eds.): Artificial Neural Networks: An Introduction to ANN Theory and Practice. Springer, Heidelberg 1995, s. 235-245.

[12] Das S.K., Basudhar P.K.: Prediction of residua friction angle of clays using artificial neural network. Engineering Geology 2008, vol. 100, nr 3, s. 142-145.

[13] Ding Wenlong, Li Chao, Li Chunyan, Jiu Kai, Zeng Weite, Wu Liming: Fracture development in shale and its relationship to gas accumulation. Geoscience Frontiers 2012, vol. 3, nr 1, s. 97-105.

[14] Dziedzic A., Pinińska J.: Zmiany prędkości podtużnej fali ultradźwiękowej podczas ściskania osiowego $w$ warunkach wysokich ciśnień $i$ temperatur $w$ wybranych rodzajach skat. Biuletyn Państwowego Instytutu Geologicznego 2011, nr 446/2, s. 129-134.

[15] Edlmann K., Somerville J., Hamilton S.A., Crawford B.R.: Predicting Rock Mechanical Properties from Wireline Porosities. SPE/ISRM 47344, Society of Petroleum Engineers 1998 , s. $169-175$.

[16] Eshkalak M.O., Mohaghegh S.D., Esmaili S.: Geomechanical Properties of Unconventional Shale Reservoirs. Journal of Petroleum Engineering 2014, vol. 2014, s. 1-11.

[17] Haykin S.: Neural networks and learning machines, vol. 3. Prentice Hall, New Jersey 2009.

[18] Herwanger J., Koutsabeloulis N.: Seismic Geomechanics: How to Build and Calibrate Geomechanical Models using 3D and 4D Seismic Data. EAGE Publications 2011, $181 \mathrm{~s}$.

[19] Jędrzejowska-Tyczkowska H., Malaga M., Wolnowski T., Żuławiński K.: Sejsmicznie konsystentne estymatory złoża węglowodorów. Projekt nr 9T12A031114.INiG, Kraków 2000.

[20] Jędrzejowska-Tyczkowska H., Słota-Valim M.: Mechaniczny model Ziemi jako nowy i konieczny warunek sukcesu w poszukiwaniach i eksploatacji złóż niekonwencjonalnych. Nafta-Gaz 2012, nr 6, s. 329-340.

[21] Khaksar A., Taylor P.J., Fang Z., Rahman K.: Rock Strength from Core and Logs, Where We Stand and Ways to Go. Conference Materials: SPE EUROPEC/EAGE Annual Conference and Exhibition held in Amsterdam, The Netherlands, 8-11.06.2009.

[22] Kowalska-Włodarczyk M., Darłak B.: Modele stochastyczne wybranych parametrów jako wsparcie konstruowania modeli geologicznych przy użyciu ANN i Fuzzy Logic. Nafta-Gaz 2011, nr 1, s. 7-13.

[23] Kowan J., Hong Ong S.: Wellbore Stability: Special Considerations for the Marcellus Shale. Search and Discovery Article 80533 2016. Adapted from oral presentation at AAPG Geoscience Technology Workshop (GTW) „Marcellus and Utica Point Pleasant”, Pittsburgh, Pennsylvania, 17-19.06.2014.
[24] Lee M.W.: Biot-Gassmann theory for velocities of gas hydratebearing sediments. Geophysics 2002, vol. 67, nr 6, s. 1711-1719.

[25] Samarasinghe S.: Neural networks for applied sciences and engineering: from fundamentals to complex pattern recognition. Taylor \& Francis, Florida 2006, 570 s.

[26] Sarkar K., Tiwary A., Singh T.N.: Estimation of strength parameters of rock using artificial neural networks. Bulletin of Engineering Geology and the Environment 2010, vol. 69, nr 4, s. $599-606$.

[27] Sayers C.: Geophysics Under Stress: Geomechanical Applications of Seismic and Borehole Acoustic Waves. Distinguished Instructor Short Course, $13^{\text {th }}$ edition from Distinguished instructor series, SEG Digital Library 2010.

[28] Slatt R.M.: Important geological properties of unconventional resource shales. Central European Journal of Geosciences 2011, vol. 3, nr 4, s. 435-448.

[29] Słota-Valim M.: Static and dynamic elastic properties, the cause of the difference and conversion methods - case study. NaftaGaz 2015, nr 11, s. 816-826, DOI: 10.18668/NG2015.11.02.

[30] Sonmez H., Gokceoglu C., Nefeslioglu H.A., Kayabasi A.: Estimation of Rock Modulus: For Intact Rocks with an Artificial Neural Network and for Rock Masses with the new empirical equation. Rock Mechanics and Mining Sciences 2006, vol. 43, nr 2, s. 224-235.

[31] Stadtmüller M., Lis-Śledziona A., Słota-Valim M.: Petrophysical and Geomechanical Analysis of the Lower Paleozoic Shale Formation, $N$ Poland. Wydawnictwo AAPG i SEG, Interpretation 2018.

[32] Varacchi B., Jaiswal P., Puckette J., Dvorkin J.: Elastic Properties of Silica-Rich Mudrocks: Woodford Shale, Andarko Basin, Oklahoma. Paper SEG 2012-1230, Society of Exploration Geophysicists 2012.

[33] Yilmaz I., Yuksek A.G.: An example of Artificial Neural Network (ANN) Application for Indirect Estimation of Rock Parameters. Rock Mechanics and Rock Engineering 2008, vol. 41, nr 5, s. 781-795.

[34] Zoback M.D.: Reservoir Geomechanics. Stanford Languita Stanford University 2017, wykłady wideo.

[35] Zoback M.D.: Stress fields - from tectonic plates to reservoir around the world. Cambridge University Press, Cambridge, Reservoir Geomechanics 2010, s. 281-287.

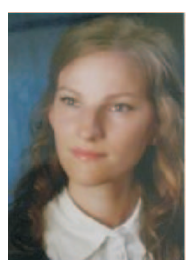

Dr inż. Małgorzata SŁOTA-VALIM

Asystent w Zakładzie Geologii i Geochemii, Laboratorium Petrofizyki.

Instytut Nafty i Gazu - Państwowy Instytut Badawczy ul. Lubicz 25 A

31-503 Kraków

E-mail:slota@inig.pl 